Katarzyna Wrońska*

ORCID: 0000-0001-6617-4415

Krakow, Poland

\title{
Erasmus of Rotterdam as a Teacher of Christian Humanism
}

\section{Erazm z Rotterdamu jako nauczyciel humanizmu chrześcijańskiego}

\begin{abstract}
Summary: The text presents the life and thought of Erasmus of Rotterdam as a humanist, an educator and a priest, and then tries to describe the Erasmian concept of humanistic religious education as arising from these three levels and ways of thinking. The purpose of this research is twofold: on the one hand, it aims to recreate this historical thought with the ambition to bring out its distinguishing features; while on the other, it is assumed that this concept can be useful to those of us today who are interested or responsible for the current shape of religious education, in theory and practice.
\end{abstract}

Keywords: humanism; Christianity; pedagogy; religious education; teacher; pupil; nurture.

* Dr hab. Katarzyna Wrońska, prof. UJ - professor of the Jagiellonian University in Kraków; Head of Department of General Pedagogy and Philosophy of Education at the Institute of Education at the Faculty of Philosophy of the Jagiellonian University in Kraków. Address: Institute of Education, Batory Street 12, r. 15, 31-135 Kraków, Poland; email: katarzyna. wronska@uj.edu.pl. 
Streszczenie: Tekst prezentuje życie i myśl Erazma z Rotterdamu jako humanisty, pedagoga i osoby duchownej, by następnie spróbować opisać powstałą ze złożenia tych trzech poziomów i sposobów myślenia Erazmiańską koncepcję humanistycznej edukacji religijnej. Cel tego badania jest podwójny, z jednej strony chodzi o odtworzenie tej historycznej myśli z ambicją wydobycia jej wyróżników, ale z drugiej - zakłada się, że ta koncepcja może być przydatna nam współczesnym, zainteresowanym bądź odpowiedzialnym za dzisiejszy kształt edukacji religijnej, w teorii i praktyce.

Słowa kluczowe: humanizm; chrześcijaństwo; pedagogika; edukacja religijna; nauczyciel; uczeń; wychowanie.

Erasmus of Rotterdam is a figure who has continuously attracted the attention of humanists (among others) for five centuries. Due to being a teacher for some time, and writing a great many texts on education, he also made a permanent mark in the history of pedagogical thought, as a thinker and educator of the Renaissance. In the following text, I refer to his immensely rich work, which is imbued with humanism - mainly pedagogical and religious in order to extract from it Erasmus' thinking about religious education. The purpose of this study is twofold. On the one hand, it is undoubtedly concerned with the reconstruction of this historical thought, with the ambition to bring out its distinguishing features; but on the other, it assumes that this concept can be useful to us today, if we are interested or responsible for the current shape of religious education. The world in which Erasmus lived and worked was very restless, marked by conflicts, wars, plagues, intolerance and ignorance. His position as a Catholic priest, and at the same time a proclaimer of ideas of humanism that referred to the intellectual achievements of antiquity, brought him fame and acclaim, as well as criticism and even condemnation. By proclaiming his praise for pagan thought and openly criticizing scholastic philosophy and the practice of monastic life, he exposed himself to easy attacks by the Church; yet he defended and consistently presented this doctrine throughout his life. On the other hand, growing out of the way of thinking of his fellow believers and brothers in the Catholic faith did not mean concessions to the Reformation. An expression of this was, for example, his dispute with Luther about free will ${ }^{1}$. Perhaps it was precisely this

${ }^{1}$ Erasmus and Luther, The Battle over Free Will, ed. Clarence H. Miller, transl. Clarence H. Miller, Peter Macardle (Indianapolis, Cambridge: Hackett Publishing Company Inc., 2012). 
non-compliance with a single doctrine or philosophical position that allowed Erasmus to maintain the position of a thinker who has been constantly present in Western culture and civilization, not just in the Renaissance world. He himself was a spokesman for maintaining the continuity of this rich cultural heritage, which I will refer to for the purpose of this study.

I assume that in today's world, with its growing conflicts and the revival of intolerance, his thought can be helpful in alleviating antagonisms, and it may also inspire conflicted parties to exceed their positions in disputes, simply based on the perspective of humanism. This approach was used by Erasmus the thinker and educator to understand religion; therefore, we should examine what this thought resulted in, what built its foundations, and to what extent we can profit from it today. Thus, Erasmus' conciliatory attitude may prove very useful again. In the clash of two positions of opponents, fighting for the exclusive right to truth, and proclaiming their arguments in the heat of battle, the peaceful attitude of the Renaissance humanist signalled a readiness for ceasefire in the name of agreement, consensus, peace, and the coexistence of arguments and people who differ but want to live in one community. In Erasmus' lifetime, this approach was assessed as conciliatory or even cowardly ${ }^{2}$; whereas today, it could indicate maturity and reason if used in public debate or in pastoral teaching, in order to alleviate the harshness of religious or political disputes. I see the humanism that embodies Erasmus' entire thought, including his approach to religion and education, as a guarantee of subjectivity in both pedagogical and religious space.

It is difficult to separate humanistic thinking from pedagogical and religious thinking in Erasmus' texts; during his life he fulfilled the roles of a humanist writer, a teacher and educator, and a priest. However, I intend to examine to what extent humanism as a philosophical orientation was foregrounded in the whole concept, in terms of exerting a fundamental influence on the clarity of Erasmus' pedagogical and religious views. Therefore, I will conduct the analysis in the following order. To begin, I will present his life and work as a humanist, then as a pedagogue (teacher and educator), and as a priest and a philosopher of Christ. In the next step, I will try to show the impact of humanism on pedagogical views, in the form of the humanistic concept of education; and then the impact of humanism on the religious views of Erasmus, in the form of Christian humanism and the philosophy of

2 Stefan Zweig, Tryumf i tragizm Erazma z Rotterdamu, transl. R. Centnerszwerowa (Warszawa: Wydawnictwo J. Przeworskiego, 1936), 25. 
Christ. I assume that this influence was mutual; hence, I will investigate if and how humanism itself developed thanks to his pedagogical and religious reflection in both cases. In this manner, based on the hermeneutic method, I intend to reveal Erasmus' original concept of humanist religious education, in which each perspective brings something of its own and illuminates the others, thus creating an original whole, with Erasmus himself as its master. In the summary, I will report the results of this work. In accordance with the intention of Erasmus himself, who believed in the universalism of the principles of humanism, I explore his concept, hoping that it may be interesting; either in individual parts or as a whole (as it turned out for me), and also from the perspective of the spiritual needs of modern Europeans.

\section{Erasmus as a humanist}

When discussing Erasmus' humanism, we must obviously bear in mind the shape that this trend took in the 16th century, rather than our contemporary one, where it carries a variety of meanings. In the Renaissance, humanism meant the renewal of the heritage of antiquity, with all its richness: this influenced languages, literature, philosophy and art. Initiated in Italy as the Quattrocento, it was a natural return to the Italians' roots. Later, it was taken up in the countries of the North, where it found numerous followers, including Erasmus. It became the Golden Age of humanity - the embodiment of the renewal of spiritual and intellectual life in those times. Italian Renaissance researchers, such as Pietro Vergerio, Vittorino da Feltre, Marsilio Ficino, Francesco Filelfo, Lorenzo Valla, Maffeo Veggio, Antonio Beccadelli and others, conducted extensive studies of ancient writing. Scholars renewed Latin according to models developed by Cicero, Seneca, Quintilian, Virgil, Augustus and Greek, by returning to the books of Plato, Aristotle, Plutarch, Lucian, Orygen, Augustine and others; and some of them studied the books of Holy Scripture in original languages, and patristic writings. In that circle, it was believed that without an insight into the ancient world, one cannot understand one's own times and the problems faced by a human being, regardless of the epoch. For some humanists of the Quattrocento, it was also a natural way to understand Christianity, which was developing in the surroundings of the Greco-Roman culture ${ }^{3}$. Thus, being a humanist in

3 William Harrison Woodward, Desiderius Erasmus concerning the Aim and Method of Education (Cambridge: the University Press, 1904), 32-39. 
the Renaissance meant being familiar with the study of classical languages, rhetoric and literature ${ }^{4}$.

It was precisely this atmosphere of studia humanitatis that Erasmus had the opportunity to encounter as a student. The school in Deventer, which he joined in 1476 at the age of nine, was run by the Brethren of the Common Life, and was at that time an important centre of humanism in the Netherlands. Reseachers of antiquity, such as Alexander Hegius or Sintheim, were associated with this school. It was also visited by Rudolph Agricola, as mentioned by Erasmus himself 5 . Erasmus' interest in culture, including classical literature, quickly crystallized in those conditions, followed by his involvement in the intense study of Latin, reading literature extensively, and writing. Under the watchful eye of teachers - mainly Sindheim, who recognized his diligent student's literary talent - Erasmus also started to write his first poetic works. From that time onwards, his school years were filled with this activity, termed studia humanitatis - and later on, his whole life too. The abilities he was demonstrating, regarding general civilization and dedication to work, as well as his first written works, quickly gave him opportunities for further study and research, which ushered him into the world of men of letters.

At the very beginning of his career, but already after his choice of a religious vocation and ordination as a priest, he drew the attention of Bishop Hendrik van Bergen, who made him his secretary and sent him to Paris to study theology. As a consequence, later on in England he met John Colet and Thomas More. They became soulmates, bound by a common interest in humanistic studies and a love for antiquity. Erasmus cooperated with Colet, who became the dean of St. Paul's Cathedral in London, and founded an affiliated school in 1510 . He wrote numerous student books, at first for teaching purposes at Colet's school; but later, after gaining public acclaim, also for other uses. In addition, Erasmus dedicated his most famous work, Moriae encomium (The praise of folly), to his second friend, Thomas More. While staying at his home accompanied by the whole More family, his wife and daughters, he recognized the benefits of the careful and comprehensive education of girls, which had been underestimated and neglected for centuries.

${ }^{4}$ Erika Rummel, "Desiderius Erasmus", in: The Stanford Encyclopedia of Philosophy (Winter 2017 Edition), ed. Edward N. Zalta, https://plato.stanford.edu/archives/win2017/entries/ erasmus/ [access: 01.09.2019].

5 Woodward, Desiderius Erasmus, 3; Erasmus, Christian Humanism and the Reformation. Selected Writings of Erasmus, ed. John Olin (New York: Fordham University Press, 1975), 32-33. 
These first meetings - clearly forming and attracting him to the ideas of humanism proclaimed in that group - turned out to be decisive for Erasmus, both for his profile of interests and for his life. After joining the group of experts in classical culture, he could - for scientific purposes - leave the monastery walls, which turned out to be too limiting for him, because they hindered his creative activity, which was his natural inclination. Erasmus' biography is widely known, so we know what kind of globetrotter he turned out to be. The better conditions he found for his studies and writing work, the longer he would stay in a given place. He lived in many European cities, including Oxford, Louvain, Antwerp, Turin, Florence, Bologna, Venice, Padua, Siena, Rome, Naples, Cambridge, and Freiburg im Breisgau, and was welcomed by friends, students and universities, as well as papal, royal and princely courts. He spent the last years of his life in Basel, and kept writing until the very end. He dedicated himself to translating and developing the intellectual output of antiquity, the Bible and patristic literature, for the benefit of scholars and pastors who would make it available to students, either in Latin schools or privately at home ${ }^{6}$.

As a humanist, Erasmus was faithful to the principles of that intellectual trend. For the purposes of this paper, I will distinguish the following: first, his preference for teaching the arts of grammar and rhetoric, at the expense of logic and philosophy (after Bruce Kimball); second, acceptance of scepticism as a general attitude in research (after Erika Rummel), which requires consideration of all parties to the dispute and finally a consensus. Both issues need to be elaborated upon, but due to their connection with pedagogical and religious topics, this will be done in the following sections of this manuscript. At this point, I would just like to point out that Erasmus' preference for oratorical artes liberales was not so much due to his antiphilosophical attitude, as to his criticism of speculative scholasticism ${ }^{7}$. A strong conviction about the importance of teaching ethics and moral education, following the example of the Ancients, spoke in favour of philosophy. On the other hand, it should be noted that as a priest, Erasmus had to find a way to reconcile the sceptical attitude with the truths of faith and the teachings of the Church. It is our task to assess if he was successful.

${ }^{6}$ Jean-Claude Margolin, Erazm z Rotterdamu, in: Myśliciele o wychowaniu, vol. 1 (Warsaw: Polska Oficyna Wydawnicza „BGW”, 1996), 341.

7 Desiderius Erasmus, The Praise of Folly and Other Writings, ed. Robert Adams (New York, London: W.W. Norton \& Company, 1989), 50-62. 
To summarize this first exploration of Erasmus' views, I would like to point out their general feature, namely universalism. In his writings, he referred to the common determinant of humanity that all people share: the reason that, through education, one can be cultivated and perfected throughout one's life. This, in my opinion, has maintained over the centuries the presence and influence of the ideas he was proclaiming. Consequently, first the humanists of the 16th century were called Erasmus followers, because they drew on his thoughts. Later, his work was used to support the ideas of the Enlightenment, and Erasmus himself was categorized as a rationalist. In the 20th century, as Rummel writes, Dilthey called him "the Voltaire of the 16 th century", and Ralf Dahrendorf coined the term "Erasmus Menschen" to describe people who were distinguished by tolerance and compassion, were guided by reason, and avoided extremism in politics. According to Rummel, an "Erasmus follower" is a person with liberal views; not so much representing a philosophical school, as showing an attitude of searching for a modus vivendi. One could also add that this is a person with a sceptical attitude. Using Erasmus' words, it is "not someone who doesn't care to know what is true or false... but rather someone who does not make a final decision easily or fight to the death for his own opinion, but rather accepts as probable what someone else accepts as certain"s. To my mind, in the era of emerging extremism and political and religious radicalism, such ideas may serve as a counterweight and moderator of moods, aggression and conflicts manifested in the public sphere. I would myself place Erasmus among those humanist writers whose message, so full of respect for the human being and human communities, can be read as a contemporary guide to living in our increasingly multicultural societies.

\section{Erasmus as a teacher and educator}

Very early in his life, just after his ordination as a priest, Erasmus was a young friar from the canon's regular monastery in Stein; he took up teaching assignments, being forced to seek a living wage while studying in Paris. The skills he had acquired in earlier years were useful: finding himself absolutely fascinated by ancient poetry and literature, he was learning Latin intensively by reading and working on classical sources and contemporary Renaissance writers. His first students were English, and they could truly

\footnotetext{
${ }^{8}$ Quoted after Rummel, "Desiderius Erasmus”.
} 
appreciate the talent of the young humanist. A few years later, one of them, Lord Mountjoy, invited him to his family home. In those years, Erasmus edited (in addition to poetical works) an appreciation letter dedicated to Robert Gaguin, who was a lecturer at the Paris University, and the author of one of the manuscripts he was working on at that time ${ }^{9}$. Subsequently, that letterthe first printed text of Erasmus - was noticed by John Colet, a theologian from Oxford University; this prompted a trip to England, which resulted in cooperation with him, as well as with Morus and other supporters of classical philosophy and literature ${ }^{10}$.

Appreciated in his teaching work and motivated by Colet's encouragement, Erasmus produced many pedagogical texts, including school textbooks. The first was the dissertation De Ratione Studii (On the Method of Study, 1511); later, there apppeared Institutio Principis Christiani (On the Education of a Christian Prince, 1516), De Pueris Instituendis (On the Education of Children, 1529); and from among the textbooks, there were for example De conscribendis epistolis (On Epistolary Composition, 1522), De civilitate morum puerilium (On good manners, 1530), as well as Colloquia in 1518 - a collection of conversations for teaching correct Latin. However, these dialogues rose far beyond the level of didactic aids provided by schools; their literary quality, satirical tone, and the range of subjects discussed there - from social, to political and religious - made them a mirror of the customs of the epoch ${ }^{11}$. The manuscript which he worked on for many years, constantly broadening and improving it, was Adaggia (Proverbs, 1500). It was also originally intended as a teaching aid in the study of Latin. Like Colloquia, the proverbs gained wider recognition, were read, renewed and translated into many languages; this was also because of the beauty of the literary form, and the multitude of references to the whole heritage of Latin and Greek culture. Erasmus drew abundantly from it, while also introducing personal reflections and criticism during the presentation of individual proverbs. In addition, in the list of handbooks I suggest including an early text by Erasmus, Enchiridion militis christiani (The Handbook of the Christian Soldier, 1503). I will devote more attention to this book in a further part of the study, in connection with the religious message of the humanist.

When analysing Erasmus' pedagogical writings, the value he attributed to education becomes clearly visible. To my mind, his involvement was due

\footnotetext{
9 Erasmus, Christian Humanism, 34.

${ }^{10}$ Woodward, Desiderius Erasmus, 7.

${ }^{11}$ Margolin, Erazm, 346.
} 
to, on the one hand, difficult personal experiences as a child, pupil, student, teacher and lecturer, as well as a monk; and, on the other hand, literature especially from the Renaissance period, which promoted a new approach to childhood and, in a broader sense, to education. This is why I will attempt to examine the main motives of Erasmus' pedagogical thought through the prism described above as the humanistic education, however, after presenting the religious background of Erasmus.

\section{Erasmus as a priest and a monk}

This would not be a full presentation of Erasmus' convictions if it were limited to his humanistic and pedagogical views, given that the views outlined so far were proclaimed by Erasmus as a priest and a monk. Unfortunately, many of his ideas were rejected by the Catholic Church, and the works in which he presented them were on the list of forbidden books. Nevertheless, Erasmus was unequivocally defending the Catholic doctrine; the best example of this was his dispute with Luther, and the defence of the Church's position regarding the issue of free will. He read much patristic literature, and was involved in the translation and critical development of manuscripts written by individual Church Fathers and early Christian writers (Cyprian, Arnobius, Hilarius, Irenaeus, Ambrose, Augustinus, Chrysostom, Basil, Origen), as well as in preparing a new translation of the New Testament from the Greek original, and finally writing textbooks for Catholic believers. Through all these activities, Erasmus contributed greatly to Christian religion, humanism and pedagogy. His theological education was also significant, as attested by the University of Turin awarding him the title of Doctor of Theology. However, his criticism of ecclesiastical institutions and scholarly theologians did not bring him credit in his own Church, and could have contributed to the condemnation of works in which he ridiculed the shortcomings of his confrères in faith. Taking into account the topic of this manuscript, it is worth mentioning a few items from the list of religious works. These are, in the order of their creation: Enchiridion militis Christiani, Moriae encomium and Institutio principis Christiani; then Paraclesis (An Exhortation to the Diligent Study of Scripture, 1516), De Libero Arbitrio Diatribe (Discussion of Free Will, 1524); as well as De vidua Christiana (On the Christian Widow, 1529); and Ecclesiastes (The Evangelical Preacher, 1535), one of the last works that he devoted entirely to faith and religion. 


\section{Erasmus as the spokesman for humanist education}

Let us return to Erasmus' pedagogical thought. The sheer number of publications devoted to education testifies to his interest in this subject. At this point I will try to recreate its main threads, hoping that I will also be able to capture its own distinctive features, which have also empowered the humanism of the author of Moriae encomium.

Erasmus' personal experiences from that period, when he himself was under the care of others and was learning, were purely negative ${ }^{12}$. This was related not only to the way children were treated, which he was not afraid to describe as barbaric, but also to the taught curriculum. He pointed out the numerous moral vices, mental laziness, harmful habits and ignorance of the church faculty ${ }^{13}$. Based on these criticisms of the existing education system, he advocated home education under the watchful eye of a parent or a private teacher. He also appreciated the value of teaching in small groups, giving the opportunity for competition and cooperation, which are conducive to learning. In this approach we can find traces of his own experience, such as learning with friends, as well as the voices of classical educators, primarily Quintilian. With regard to girls' education, it is difficult to judge clearly what had the strongest impact on Erasmus, as both Italian humanists and some examples of educated girls in his environment (for instance Morus' daughters), as well as women he had heard about (Marguerite of Navarre or Caritas Pickheimer), persuaded him to change the existing practices and views on women. All in all, examples of Erasmus' appreciation of women's education have to be recognized (for instance, in Colloquia: "The Abbot and the Learned Lady" and "The New Mother"). Even if they were to prepare themselves for the roles of wives and mothers, or for religious life, their education was no longer considered an obstacle to the fulfilment of their vocation; on the contrary, according to Erasmus, it became invaluable in the proper education of offspring, and useful and resourceful in difficult life situations when they had to support themselves.

Neither can we overlook the impact of humanism on Erasmus' pedagogical views. This trend itself was saturated with educational motifs; it also outlined the educational ideal, so that it was impossible for him to omit this

\footnotetext{
${ }^{12}$ Erasmus, Christian Humanism.

13 Erasmus, The Praise.
} 
subject, having already joined the group of humanists. It was a very classical approach to virtue, which included Socrates' ethical intellectualism, the education programme offered by sophists, and motivation to learn a decent life for the sake of demos; this was followed by Aristotle and ethical schools throughout the Hellenistic era, and then the flourishing of ethical and educational thought in the Roman Empire. All of this pointed to the actions of education that formed and improved human nature; and Erasmus took over this approach. The distinguishing feature of humanism that I emphasized earlier, namely the preference for rhetoric over dialectics, is a strong foundation of his educational thinking. Putting ethics above logic (dialectics) initially meant putting character-shaping above knowledge. But this was immediately followed by praise for liberal education (the liberal arts), which also favoured the formation of character. This list should be complemented with Erasmus' indications relating to civilization (good manners). I would also consider the ethical references we may encounter here. For instance, his textbook stood out from others - for example, Il cortegiano (The Courtier) by Castiglione - because he wanted something more than just aesthetics, otherwise called "the elegance of behaviour". At this point, it is impossible not to notice the position of Kimball, who finds in Erasmus' texts only an aesthetic resonance of the classical texts of antiquity, while an ethical dimension he finds in Erasmus' philosophy of Christ ${ }^{14}$. In my opinion, the ethical merits of ancient philosophy, as indicated by Erasmus, cannot be neglected. However, the matter of free will, which is a crucial issue when speaking about morality, derived by Erasmus from Christian assumptions, provides support for Kimball's interpretation. However, this means that Erasmus' attitude towards religion also affected his pedagogical views; I will elaborate on this point later.

To return to De civilitate, this was a guide to good breeding, understood as an expression of the inner state of the soul and not a game for show (permitted by Castiglione). This is visible in, for example, the initial and final paragraphs of his text:

now although external decorum of the body proceeds from a well-ordered mind, yet we observe that sometimes even upright and learned men lack social grace because they have not been taught properly. I do not deny that external decorum is a very crude part of philosophy, but in the present climate of opinion

${ }^{14}$ Bruce Kimball, Orators \& Philosophers. A History of the Idea of Liberal Education (New York and London: Teachers College, Columbia University, 1986), 87-88. 
it is very conducive to winning good will and to commending those illustrious gifts of intellect to the eyes of men ${ }^{15}$.

And later on:

the essence of good manners consists in freely pardoning the shortcomings of others although nowhere falling short of yourself: in holding a companion no less dear because his standards are less exacting. For there are some who compensate with other gifts for their roughness of manners. Nor should what I have said be taken to imply that no one can be a good person without good manners. But if a companion makes a mistake through ignorance in a matter that seems of some consequence, then the polite thing to do is to advise him courteously of it in private ${ }^{16}$.

This humanistic approach to the discussed part of education - not the most important one, yet necessary - which had been neglected before, might have contributed to the book's great popularity throughout Europe when Erasmus was alive. Its validity is confirmed by new contemporary translations and adaptations of this work, to suit modern educational needs ${ }^{17}$.

On the other hand, we owe truer nobility to the liberal arts. According to Erasmus, "man was not born but made man"18, and "man, unless he has experienced the influence of learning and philosophy, is at the mercy of impulses that are worse than those of a wild beast". ${ }^{19}$ Therefore, we need education; and this, including care for good manners, should begin in the first years of a child's life - that is, in the family. Such education is not just about care and nurturing, but also concerns offering a child opportunities to learn, from the moment when he or she is capable of doing so. In Erasmus' opinion, the development of speech was a sign of readiness to learn. This should be

15 Erasmus, "On Good Manners for Boys. De civilitate morum puerilium”, trans. Brian McGregor, in: Collected Works of Erasmus, vol. 25, ed. J. K. Sowards (Toronto, Buffalo, London: University of Toronto Press, 1985), 273.

${ }^{16}$ Ibidem, 289.

17 see for example Erasmus of Rotterdam, A Handbook of Good Manners for Children, trans. Eleanor Merchant (London: Preface Publishing, 2008).

18 Erasmus, "A Declamation on the Subject of Early Liberal Education for Children. De pueris statim ac liberaliter instituendis declamation", transl. Beert C. Verstraete, in: Collected Works of Erasmus, vol. 26, ed. J. K. Sowards (Toronto, Buffalo, London: University of Toronto Press, 1985), 304.

19 Ibidem, 305. 
followed by a curriculum adapted to the abilities and talents of a child. $\mathrm{He}$ supported his thinking with Greek and Roman classics, including Plato, Aristotle, Quintilian, Isocrates, Plutarch, and also the words of Seneca, "that no age is too old for learning" ${ }^{20}$. Like Aristotle, he differentiated three factors in education, which condition human happiness: natura, ratio and exercitatio. These are translated as nature ("man's innate capacity and inclination for the good"), method ("learning which consists of advice and instruction") and practice ("exercise of a disposition which has been implanted by nature and moulded by method" $)^{21}$. Due to education, a well brought-up child will be "a son who will be a faithful protector of his family, a good husband to his wife, and a solid and useful citizen of his country"22. Erasmus was convinced that it is better for a child to be occupied with learning than to remain idle. As he put it, "being occupied with his studies, a child will avoid the common pitfalls of youth - for learning is something that engages the entire person - and this is a blessing which should not be undervalued"23. His purely humanistic attitude to educating children was demonstrated by the fact that Erasmus blamed poor learning results not on a student's lack of ability or intention, but on neglect and wrong teaching methods ${ }^{24}$. It is easy to notice a reference to his own experience: Erasmus criticized the poor mental and moral condition of teachers on many occasions. He was also critical of ubiquitous medieval scholastic methods, including memorizing, corporal punishment, imitation and power over the student, which enforced the pupil's full subordination to the teacher, and strongly rejected such an approach to teaching. This raises the question of what teaching methods he himself proposed. Here we should refer to the distinguishing features of humanism, listed in relation to the previous point.

Education requires a climate of cooperation and interest in the subject of learning. Instead of memorizing, Erasmus recommended exercising creative invention and developing one's own style in oral and written statements, based on readings of many different authors, and a critical and understanding-based assessment of their works. According to Erasmus, scholastic disputes were only useful in a technical sense, because they enabled practising efficiency in counter-argumentation and contradicting the opponent's argu-

\footnotetext{
${ }^{20}$ Ibidem, 319.

${ }^{21}$ Ibidem, 311.

22 Ibidem, 302.

23 Ibidem, 297.

${ }^{24}$ Rummel, "Desiderius Erasmus".
} 
ments. Instead, he proposed rhetorical exercises (speaking skills), which are sensible, because when they are used in discussions on ethical issues, they teach how to develop a common position - a consensus, in an atmosphere of agreement, cooperation and friendly exchange of opinions (which are at first different, but later reach some kind of consensus) (see for example Colloquia: "An Inquiry into Faith", "The Religious Feast"). The education through which children acquire virtues and literary knowledge (early liberal education) was, according to Erasmus, an instructive education, and thus also a moral education.

As a pedagogue, Erasmus adopted many humanistic ideas, though modifying them in his own way. According to Rummel, these included the effectiveness of cooperative rather than coercive methods; the ability of both sexes to benefit from education; and the importance of internalizing the material taught. At this point - at the beginning - I personally find Erasmus to be firstly a critic of fanaticism, believing in the power of peace, harmony and tolerance; secondly, a critic of the institutions which he was subordinate to, including the Church, due to their dogmatism and excessive power (which I will discuss further later on); and finally, I find Erasmus to be a critic of force persuation, who believed in the power of independent minds that choose according to the strength of arguments, not compulsion. He introduced his personal touch into humanism as a result of his involvement in the problems of pedagogy. In my opinion, his output included, firstly, an encouragement of criticism, i.e. focusing on one's own reasoning and open mind; secondly, the depreciation of ignorance as a source of evil, as a condition unworthy of man - that is, reaching out to every child (who has the right to learn) through the benefit of education; thirdly, praising civilization's achievements (including printing, geographical discoveries but also good manners); and fourthly, appreciation of the significance of passion, curiosity about the world, and people - indeed, the task of education is to develop and maintain this human feature. These values are the hallmarks of Erasmus, who loved classical languages, as a symbol of the common heritage of our civilisation. His knowledge of them enabled communication and cooperation, which made him "the teacher of Europe" 25 , whose name is associated nowadays with a student exchange programme. Taking into consideration this aspect of his convictions, one can again conclude that they are currently relevant, given the increase in populist, conformist, nationalist, xenophobic,

${ }^{25}$ Margolin, Erazm, 346-350. 
and generally anti-enlightenment moods in our societies - to which Erasmus' view can act as an invigorating counterweight and countermeasure.

\section{Erasmus' Christian Humanism and Philosophy of Christ}

When studying the strictly religious writings of Erasmus, we get the impression of a postulated new piety, pietas, which deviates from ceremonies, their external manifestations, and the cult of saints. This signalled a return to the source, namely Scripture, and early Christian thought, which embody the philosophy of Christ. The personal exploration and reflection on piety, and living according to its indications, brings fulfillment and a sense of meaningfulness.

According to Erasmus, anyone could become a theologian, provided they read the holy books with understanding. These allow us to build a personal relationship with God, to look at ourselves, to discover and develop our inner life, and then to have the courage to decide to live a decent life, bringing benefits also to our neighbours and community. This does not require the mediation of knowledgeable theologians, who reflect on and teach complex doctrinal questions and dogmas. Devotio moderna, or the new piety, was to be based on faith, love of one's neighbour, and striving for union with God in eternity. However, the life of a Christian was not the only possible model for a good, happy life. Erasmus appreciated the proposals formulated in pagan philosophy and its ethical schools. Nevertheless, the model of Christian moral life was a new order for him $^{26}$. We can read in Pietas puerilis that piety is "the undefiled worship of the Deity and the keeping of his commandments". The indications are as follows:

First that we think rightly and reverently of God and the Sacred Scriptures and not only fear God as Lord but also love him with our whole hearts as a most gracious Father. Second, that we do our utmost to keep ourselves blameless, that is, injure no one. Third, that we practice charity, that is, insofar as possible deserve well of all men. Fourth, that we be long-suffering, inasmuch as this enables us to bear patiently the ills we cannot remedy, forgoing vengeance and not returning evil to evil' ${ }^{27}$.

${ }^{26}$ Woodward, Desiderius Erasmus, 47.

27 Erasmus, "The Whole Duty of Youth", in: Collected Works of Erasmus, vol. 39, ed. James K. McConica (Toronto, Buffalo, London: University of Toronto Press, 1997), 92. 
He showed this even more clearly in Enchiridion, where he argued that a Christian with his faith in Christ is called to do much more than the natural good deeds, of which pagan literature can provide many examples.

For Erasmus, the philosophy of Christ was the formula for a life of following the Gospel as the Good News; that is to say, following Christ, who is the author and guarantor. On the one hand, Moriae encomium ironically described the superiority of ignorance (and thus the superiority of faith over religious knowledge and practices), and Paraclesis convincingly argued in favour of reading Scripture, the treasury of Christian knowledge; whereas Enchiridion (or Erasmus catechism, as the translator Maria Cytowska calls $\mathrm{it}^{28}$ ) was an authentic textbook, a guide describing the principles of godly life. Importantly, it addressed adults who are able to face the unambiguous and demanding call of Christ, the Teacher of the art of life. Rummel very accurately described the characteristics of piety according to the Erasmus' philosophy of Christ, pointing out that it "is an internal quality independent of the outward observance of rites; it is perfected through divine grace; and it is inclusive, that is, open to all'"29.

The philosophy of Christ as propagated in the writings of Erasmus was, as we can see, thoroughly illuminated by humanism. In this way, it became a part of Christian humanism, together with Vergerio, Vittorino or Ficino (alongside the religiously indifferent humanism developed in the Renaissance, represented by Filelfo, Valla or Beccadelli). Within this concept, devotio moderna symbolized an attitude of avoiding everything that humiliates and exalts, with the aim of educating a Christian to be devoted to work, to rely on himself, to be kind to others, humble, and ardent in faith. It was Erasmus' contribution that made such a description possible. Let us recall the two characteristics of humanism that we attribute to him, which are: the preference for teaching rhetoric and ethics (namely, studia humanitatis) over logic and speculative philosophy; and the sceptical attitude that allows us to take into account all the disputing parties and arrive at a final consensus. Undoubtedly, the first of these attributes is crucial, as it indicates Erasmus' preference for practical philosophy, which refers directly to life and is applicable within it. Erasmus was shocked by the hypocrisy of the clergy, which, on the one hand, proclaimed truths detached from life in a language incomprehensible to the people; while on the other, it failed to meet the ideal of

${ }^{28}$ Maria Cytowska, "Od thumacza", in: Erazm z Rotterdamu, Pisma moralne. Wybór (Warszawa: PIW, 1970), 22.

29 Rummel, "Desiderius Erasmus". 
Christ's humility, love and service to those in need. The Enchiridion handbook was prepared precisely for the purpose of serving as a weapon, and at the same time as a guide, defending the Christian from the temptations of the world and indicating what principles to follow. As far as schoolchildren were concerned, the liberal studies were to be as practical as possible: in other words, related to facts. Meanwhile, children were to derive and adopt patterns of decent life and piety from practical examples of the good life, given by their teachers, caretakers, or communities of believers. Erasmus indicated this clearly in the initial fragments of De civilitate: "the task of fashioning the young is made up of many parts, the first and consequently the most important of which consists of implanting the seeds of piety in the tender heart" 30 . One might wonder whether there is a contradiction between, on the one hand, criticism of ignorance, and on the other, arguing for untaught faith. How did Erasmus solve that problem? To answer this question, we need to move to the next, third step of our analysis, where we will combine all three perspectives that characterize his convictions: humanistic, pedagogical and religious ones. I would like to present this approach in the form of a humanistic religious education.

To summarize this phase of the study, I will emphasize two characteristics of Erasmus' humanistic religious thinking. There is, on the one hand, an image of man as a being endowed with the natural qualities of reason, who is enriched by believing in Christ and establishing a relationship with him, which triggers an internal transformation. On the other hand, there is the image of a loving God who gives man free will and grace, whose evangelizing message can be discovered by everyone by reading Scripture, and which should therefore be commonly accessible. This image creates a model of the Christian life, which reconciles the rationality of human reason with the irrationality of feelings and faith in grace. Faith does not require the abandonment of nature, nor does it separate one from the world, and Christianity itself thereby loses its religious exclusivity ${ }^{31}$. This is a (new) piety that does not feed on scholastic knowledgeability and does not perform ritual deeds, rites or ceremonies. It is a morality based on love and trust in God, on listening to and following His teachings, on purity of heart and good will, which ennobles human nature and is visible in attitudes, actions and relationships with others; moreover, it is accessible to everyone, and therefore as egalitari-

30 Erasmus, "On Good Manners", 273.

${ }^{31}$ Leszek Kołakowski, Erazm i jego Bóg, in: Erazm z Rotterdamu, Podręcznik żolnierza Chrystusowego, transl. Juliusz Domański (Warszawa: PWN, 1965), VIII. 
an as possible. It is a message that can be grasped not only by Christians, but also, as Kolakowski admits, more generally by those who are not indifferent to Christianity, because it belongs "to the same history and the same culture in which we all participate" 32 .

\section{Erasmus' concept of humanistic religious education}

Building upon this twofold basis, consisting of pedagogy and Christianity filled with humanism, and vice versa, let us examine what Erasmus turned out to be a teacher of, and what the mastery of his message lies in. Furthermore, what lessons can we learn from this today? It is precisely on the basis of education that we can see the problem we face, when we want to reconcile the order of reason, rooted in knowledge and scepticism, with irrational untaught faith. With the adoption of the assumption of free will, the whole philosophy of Erasmus becomes optimistic. But when confronted with the action of sacrum, this optimism had to show its limits. The point is that, after taking into consideration the dimension of God's grace, education, despite its crucial importance, had to decrease its significance (to uphold the primacy of God's actions). Learning does not guarantee our faith; therefore, education is not omnipotent. The humanistic measure of humanity was based on the ability to pursue perfection; indeed, the whole paideia was filled with such a message. However, the religious measure of humanity had to reshuffle the components of education. Raising children in the spirit of freedom, and thus with the order to respect the individual child's interests and inclinations (the merits of humanism), was to consist in Erasmus' "liberation of the child's soul from the bonds of ignorance and bodily iniquities and the creation of a truly free man, that is, a man capable of disposing of reason and free will" (merits of Christianity) ${ }^{33}$.

Consequently, along with relying on the doctrine of the Church in relation to free will, Erasmus paradoxically had to limit the scope of his scepticism. This distinct feature of Erasmus' humanism, which was the basis for promoting critical attitudes, and was guided by reason in the course of liberal education, rather than succumbing to authority, could not be applied to Scripture. As Erasmus put it, "I explicitly exclude from Scepticism whatever is

\footnotetext{
${ }^{32}$ Ibidem, XVIII.

${ }^{33}$ Cytowska, "Od thumacza", 13.
} 
set forth in Sacred Scripture or whatever has been handed down to us by the authority of the Church" ${ }^{34}$. As we can see, he considered the teaching of the Church (sacred by tradition and consensus) as exempt from scepticism, but only where Scripture requires clarification. One can, therefore, rely on the Church's decrees, but "especially those issued by general councils and fully approved by a consensus of the Christian people" 35 .

Was religious education then to be tailored to schooling needs? Erasmus himself, as the critic of school teaching, did not exclude such an option. We can use the example of the conversation between two colleagues, Gaspar and Erasmus, in Pietas puerilis (The Whole Duty of Youth). This deals with Gaspar improving himself in piety; as a grammar-school pupil, he implores "the aid of Christ, as if our effort would be ineffectual without his help", and he studies "as if he would grant no help except to one who works hard" 36 . There is no reason to doubt that this is the position of the author himself; one of the passages even reveals the presence of personal similarities, namely when the character is asked about the choice of vocation. Gaspar declares in response: "I am resolved not to commit myself to marriage, the priesthood, monasticism - or any other mode of life I can't free myself from afterward until I know my own mind very clearly" ${ }^{37}$. And so he reveals three priorities in his life; that is, three things he will take care of in the meantime: "first, to improve in conduct. Second, if I can't do that, to safeguard my innocence and reputation unstained. Finally, to apply myself to literature and other branches of study that will be useful in whatever career I may follow" ${ }^{\prime 3}$. His exceptional maturity is not self-generated; in the dialogue, Gaspar recalls John Colet as his spiritual guide ${ }^{39}$. These fragments indicate the presence of religious education only at school, and not elsewhere. However, this was a special institution, because it was founded and run by Erasmus' friend, for whom, as we know, he wrote textbooks. Therefore, it is not possible to simply transfer this example into the reality of contemporary secular schools.

${ }^{34}$ Erasmus, "A Warrior Shielding A Discussion of Free Will against Enslaved Will by Martin Luther, book one. Hiperaspistes liber unus", transl. Clarence H. Miller, in: Collected Works of Erasmus, vol. 76, ed. Charles Trinkaus (Toronto, Buffalo, London: University of Toronto Press, 1999), 118, quoted after Rummel, "Desiderius Erasmus".

35 Ibidem, 127, quoted after Rummel, "Desiderius Erasmus".

${ }^{36}$ Erasmus, "The Whole", 93.

37 Ibidem, 98.

38 Ibidem.

39 Ibidem, 99. 
Hence, the religious formation of children and young people today - as proposed by Erasmus - would, I propose, find optimal guidance in the Church and in the family - firstly, as religious teaching and participation in Masses; and secondly, as practising the virtues and good manners in the family, as a natural environment for the life and growth of children. Erasmus writes about this in Enchiridion, presenting the sixth rule of the Christian life, according to which: "It is that the mind of one who aspires after Christ should be in complete disaccord with the actions and opinions of the crowd and his model of piety should be Christ alone no other. For he is the sole archetype, and whoever departs from it even in the slightest deviates from what is right and runs outside the true path" ${ }^{40}$. He then recommends that

it should be the chief care of Christians that from the cradle onwards, amidst the blandishments of nurses and the kisses of parents, under the tutelage of their teachers, children should imbibe convictions worthy of Christ, because nothing sinks more deeply into the mind or adheres to it more tenaciously than that which is instilled in it in early years ${ }^{41}$.

However, the religious education introduced by Erasmus was not limited to childhood and school years. His most important religious writing, Enchiridion, which is helpful in the cultivation of spiritual life, was directed at adults. As we can read there:

there is no time of life when this rule [that our model of piety should be Christ alone and no other] should not be put into practice so that all vulgar errors may be pulled out of the mind by the roots and salutary opinions be put in their place and so reinforced that nothing will be able to dislodge them ${ }^{42}$.

As it was a coursebook, Erasmus listed some rules (22 altogether) for anyone who wanted to live a decent pious life. This provided rule after a rule, virtue after a virtue, which one could master using that guidebook. The same writing offered us an axiological solution to the conflict between knowledge and faith in God. The solution was presented in the fourth rule of Christian

${ }^{40}$ Erasmus, "The Handbook of the Christian Soldier. Enchiridion militis christiani", in: Collected Works of Erasmus, vol. 66, ed. John W. O'Malley (Toronto, Buffalo, London: University of Toronto Press, 1988), 84.

${ }^{41}$ Ibidem, 85.

${ }^{42}$ Ibidem, 85. 
life, according to which Christ should be placed before us as the only goal of our life ${ }^{43}$. Erasmus reminds us of three categories of things that form a kind of hierarchy of goods in the life of a Christian. These include, firstly, things "so evil that they can never be considered good, such as to avenge a wrong or to bear ill will towards someone"; secondly, things "so intrinsically good that they cannot become evil, such as wishing well to all men, helping one's friends by honest means, hating vice, and enjoying pious conversations"; and finally, neutral things "such as good health, beauty, strength, eloquence, learning and the like. Of this last class of things none should be sought after on its own account nor made use of to a greater or less extent except in so far as it leads to the supreme goal". The above-mentioned goods include learning, followed by knowledge. According to Erasmus, "knowledge is of more assistance to piety than beauty or physical strength or wealth" ${ }^{\text {" }}$. This ranks it first, though among neutral goods. He ranked the following goods after knowledge: "good health, intellectual gifts, eloquence, beauty, strength, rank influence, authority, prosperity, reputation race, friends and family possessions" ${ }^{45}$. This proves that contemporary school education which focuses on knowledge, including religious learning, is subordinate to the moral life of a Christian, which means piety, through which the human bond with God is manifested. Therefore, religious education according to Erasmus is an interesting example of reaching beyond knowledge and reason by practising a pious, virtuous life, and - beforehand - preparing for such life, by introducing oneself to sacrum and learning the mysteries of the truths of the faith.

The quoted excerpts allow us to draw one more conclusion in favour of religious education, as understood in the presented way; this concerns the role of the teacher within it. As the emphasis shifts towards simplicity of faith, the teacher's knowledgeability stops being crucial. Erasmus criticized the teaching of the clergy many times, including knowledgeable scholars whose lives were not in line with the principles of Christianity, and did not evidence faithfulness to God's commandments or to imitation of Christ. If God was to be - in Erasmus' eyes - the highest goal, then He was also becoming a teacher - that is, a master of life, towards whom all, including the scholars, remain disciples. The pedagogical relation in religious education is preserved, but the model for it is the reference to God, the teacher, towards whom the believers are His children and disciples.

\footnotetext{
${ }^{43}$ Ibidem, 61.

${ }^{44}$ Ibidem, 61-62.

${ }^{45}$ Ibidem, 62.
} 
Set out in this way, the priorities of religious education did not mean that Erasmus disregarded the role of teachers in deepening human religiousness and the reference to God. After all, he himself played that role, and even prepared teaching aids, including a guide to Christian life. According to him, Scripture should be read by everyone, and in their native languages, so that it can be used in everyday life, at work, when travelling, or during rest because of the invigorating value of the words spoken and the relationship built with God. He keeps his scholarly piety, but employs it as an attitude of respect for the limitations of human understanding. He illustrated it with the figure of St. Jeremiah, who was for him the model of a scientist: "as the Christian scholar par excellence, combining Ciceronian eloquence with a thorough understanding of theology and a devout spirit with a holy life" 46 . The eloquence of the preacher is precisely about this: to teach, to move, but also to transform and to enchant; that is, to be carried away by the soul, and not only to influence the mind. Here we can see how the pastor has to fulfil the role of not only a teacher but also an educator, awakening and attracting people to the Gospel.

\section{Conclusions}

Erasmus' religious education is to a large extent a humanistic education, which is morally shaping, but differentiated according to the age of learners. For children, it has provided an introduction to Christianity through its practice in the family and Church, and education in the liberated arts; while for adults, it enabled improvement and self-education in the field of Christian morality and religion.

The general review of Erasmus' thought - especially the textbooks and manuals written for children and adults, to familiarize them with moral and religious content - allows us to conclude that he would not bring religious education as such to a public school, but would support parents who educate their children religiously, and pastors in parishes who conduct religious education. In schools, he would recommend broadness of knowledge, including ethics and philosophy, which would be the basis, common ground and tool for each student to develop and improve himself comprehensively, through contact with cultural assets. I think Erasmus would approve if Chris-

${ }^{46}$ Rummel, "Desiderius Erasmus". 
tian ethics and philosophy were to be found within the framework of liberal education, presenting a Christian point of view alongside other ethical and philosophical proposals. However, the humanities would have to be taught in schools based on the principles of scepticism, as is the whole range of school knowledge, which is subject to research and criticism. This would include the religious contents, which are considered as a manifestation and a huge chapter of the humanities. Consistently, providing an introduction to doctrine with the intention of instilling strong beliefs means initiating and convincing students of the truths of faith; this would be an optimal formula for implementating it in places of worship and people's everyday practice at home, which means outside the school. While the order of faith is governed by its own laws and needs appropriate symbols and practices to be expressed (e.g. prayers and the virtuous life), the school - also governed by its own laws, as a separate practice - can prepare the ground (basis) for faith, by means of knowledge. Furthermore, faith, which is celebrated elsewhere, may be complemented with knowledge and criticism. It is also worth considering whether it would be possible to adapt The Handbook of the Christian Soldier to the needs of a contemporary man seeking ways of internal development and spiritual perfection, or a search for meaning - just as the editor of the manual of good manners, Eleanor Merchant, modernized Erasmus' thoughts on civilisation ${ }^{47}$.

Erasmus' Christian humanism can be reduced to a formula: What kind of a man you are, that kind of Christian you will be. Humanistic education as a basis for religious education, regardless of religious beliefs and with the guarantee of subjectivity, could be applied as a connecting factor today, in a divided and quarrelling world, as a common part of all education, beyond worship, and complemented by religious initiation.

I have entitled the above text to emphasize the teacherly dimension of Erasmus' achievements in favour of Christian humanism. I must admit that I learnt much about this concept from him, understood it better, and even convinced myself of its truth. This proves that, at least in my case, Erasmus was an effective teacher and educator. However, I leave all these considerations to the readers for further evaluation. Even if we exclude religious meaning from his message, I think that he can be a teacher for our times, due to his attitude of praising learning regardless of age, and taking advantage of the achievements of mankind; this approach connects rather than divides,

47 See footnote 18. 
and enables us to think critically. If, in turn, this religious dimension is added to it, Erasmus can be a spiritual teacher who convincingly advises us to learn not so much from him, but directly from the divine source, by reading and listening to God's words. He recommended this teaching as a permanent reference, for one can only be a disciple before God. Thus, Erasmus' message is a solution that meets the need for understanding and faith at the same time. He himself was a teacher, a humanist and a Christian, with all three dimensions interacting with his own contribution. This contribution has guaranteed its credibility; without it, it is difficult to imagine a good education.

\section{References}

Cytowska, Maria. “Od tłumacza”. In: Erazm z Rotterdamu, Pisma moralne. Wybór, 5-26. Warszawa: PIW, 1970.

Erasmus and Luther. The Battle over Free Will, ed. by Clarence H. Miller. Transl. Clarence Miller, Peter Macardle. Indianapolis, Cambridge: Hackett Publishing Company Inc., 2012.

Erasmus. Christian Humanism and the Reformation. Selected Writings of Erasmus, ed. John Olin. New York: Fordham University Press, 1975.

Erasmus. "A Declamation on the Subject of Early Liberal Education for Children.

De pueris statim ac liberaliter instituendis declamation". Transl. Beert C. Verstraete. In: Collected Works of Erasmus, vol. 26, ed. J.K. Sowards, 291-346. Toronto, Buffalo, London: University of Toronto Press, 1985.

Erasmus. "On Good Manners for Boys. De civilitate morum puerilium". Transl.

Brian McGregor. In: Collected Works of Erasmus, vol. 25, ed. J.K. Sowards, 273-289. Toronto, Buffalo, London: University of Toronto Press, 1985.

Erasmus of Rotterdam. A Handbook of Good Manners for Children. Transl. Eleanor Merchant. London: Preface Publishing, 2008.

Erasmus. "The Handbook of the Christian Soldier. Enchiridion militis christiani".

In: Collected Works of Erasmus, vol. 66, ed. John W. O'Malley, 1-127. Toronto, Buffalo, London: University of Toronto Press, 1988.

Erasmus, Desiderius. The Praise of Folly and Other Writings, ed. Robert Adams. New York, London: W.W. Norton \& Company, 1989.

Erasmus. "A Warrior Shielding. A Discussion of Free Will against Enslaved Will by Martin Luther, book one. Hiperaspistes liber unus". Transl. Clarence H. Miller. In: Collected Works of Erasmus, vol. 76, ed. by Charles Trinkaus, 91-298. Toronto, Buffalo, London: University of Toronto Press, 1999. 
Erasmus. "The Whole Duty of Youth". In: Collected Works of Erasmus, vol. 39, ed. James K. McConica, 88-108. Toronto, Buffalo, London: University of Toronto Press, 1997.

Kimball, Bruce. Orators \& Philosophers. A History of the Idea of Liberal Education. New York and London: Teachers College, Columbia University, 1986.

Kołakowski, Leszek. "Erazm i jego Bóg”. In: Erazm z Rotterdamu, Podręcznik żołnierza Chrystusowego, transl. Juliusz Domański, VII-XVIII. Warszawa: PWN, 1965.

Margolin, Jean-Claude. "Erazm z Rotterdamu”. In: Myśliciele o wychowaniu, vol. 1, 339-361. Warsaw: Polska Oficyna Wydawnicza „BGW”, 1996.

Rummel, Erika. "Desiderius Erasmus". In: The Stanford Encyclopedia of Philosophy (Winter 2017 Edition), ed. Edward N. Zalta. https://plato.stanford.edu/archives/win2017/entries/erasmus/ [access: 01.09.2019].

Woodward, William Harrison. Desiderius Erasmus concerning the Aim and Method of Education. Cambridge: the University Press, 1904.

Zweig, Stefan. Tryumfi tragizm Erazma z Rotterdamu. Transl. R. Centnerszwerowa. Warszawa: Wydawnictwo J. Przeworskiego, 1936. 
